DOI: $10.25140 / 2411-5363-2021-3(25)-187-192$

UDC 621.941-229.3:621.396.9:004.73

\author{
Marek Vagas ${ }^{1}$, Alena Galajdova ${ }^{2}$ \\ ${ }^{1}$ Doctor of Technical Sciences, Associate Professor, Faculty of Mechanical Engineering, \\ Department of Industrial Automation and Mechatronics \\ Technical University of Kosice (Kosice, Slovakia) \\ E-mail: marek.vagas@tuke.sk. ORCID iD: https://orcid.org/0000-0002-8660-8484 \\ ${ }^{2}$ Full Professor, Faculty of Mechanical Engineering, Department of Industrial Automation and Mechatronics \\ Technical University of Kosice (Kosice, Slovakia) \\ E-mail: alena.galajdova@tuke.sk. ORCID iD: https://orcid.org/0000-0003-0128-4191
}

\title{
PROCESS MONITORING BASED ON RFID TECHNOLOGY
}

The article deals with process monitoring in an automated workplace from the company FESTO using RFID technology. It contains a detailed software and hardware configuration and the programming of the RFID read head (BALLUFF) in the Siemens software environment (TIA Portal). Furthermore, the article aims to point out the possibilities of processing data obtained in such a form. Another activity is the ongoing evaluation of these data and their projection into a graphical format (e.g., trend graphs).

Keywords: RFID technology; automated workplace; sensing head; BALLUF.

Fig.: 6. References: 7.

The urgency of the research. Increasingly complex automation of production lines and entire technological processes brings with it the necessary need for real-time data processing. In addition, each final product goes through certain production stages, so monitoring its status and always overview the state is needed. As one of the commonly available and often deployed technologies, RFID offers comprehensive and fully automatic identification of products and sharing of information obtained in this way across individual levels of management.

Target setting. This technology (unlike, e.g., barcodes) allows its wide deployment in common areas of life, e.g., in-car immobilizers, contactless identification cards, smart cards on public transport, attendance systems, etc. In addition, in this way, products can be quickly and unambiguously identified or counted, and the tag does not even have to be in a visible place. RFID technology allows scanning up to several hundred pieces of products simultaneously, e.g., impossible with barcodes.

Actual scientific researches and issues analysis. RFID technology has been on the rise only in the last few years (mainly in Slovakia), and it is usually deployed only by the most significant corporate companies [1]. These facts point to the relative novelty of the technology as well as lingering concerns and doubts [2]. The most common reason for the deployment of this technology is the effort to track products or goods. However, RFID also plays a significant role in improving storage, simplifying, and streamlining warehouse operations or maintenance [3].

Most corporate companies that have already decided to implement RFID in their processes, lines, etc have never regretted this move because they realized that the technology opened up new opportunities and shortened payback time. Thus, some companies seem to be slowly and gradually beginning to realize the potential of RFID technology and are preparing to seize this opportunity [4]. Two fundamentally different RFID design approaches for transferring power from the reader to the tag: magnetic induction and electromagnetic (EM) wave capture. These two designs take advantage of the EM properties of an RF antenna - the near field and the farfield. Depending on the tag type, both can transfer enough power to a remote tag to sustain its operation - typically between $10 \mu \mathrm{W}$ and $1 \mathrm{~mW}$ [5].

Future research should focus on comparing more than two to three automation practices like MRP, VMI, and RFID to give a more realistic view of the impact of inventory automation practices on the operational efficiency of manufacturing firms. The objective measurement will provide more accurate information for better analysis. The same study can be applying to other sectors like textile, chemical, and retail [6]. 
Analysis of existing research and publications. Previously published research in RFID technology deployment confirms its undeniable advantages for corporate companies and individual requirements. At the same time, it is necessary to point out the remaining concerns (mainly) of SME companies, which are afraid of the initial investment costs. However, current research has shown the rise of this technology and the undeniable savings that will accrue to both suppliers and customers.

Article objective. This paper aims to implement and subsequently test the usability of RFID technology on a specific example of an automated workplace of FESTO. The document includes both configuration (hardware and software) and an outline of a solution for processing the obtained RFID data.

General overview of the system. By introducing RFID technology at our selected automated workplace from the FESTO Company, we will better understand the process performed on this line. Using RFID, we want, e.g., to record the time of each operation and the time the product spent on the line. At the same time, it is possible to evaluate the number of passes of the handling truck over the line in a specific time (Fig. 1).

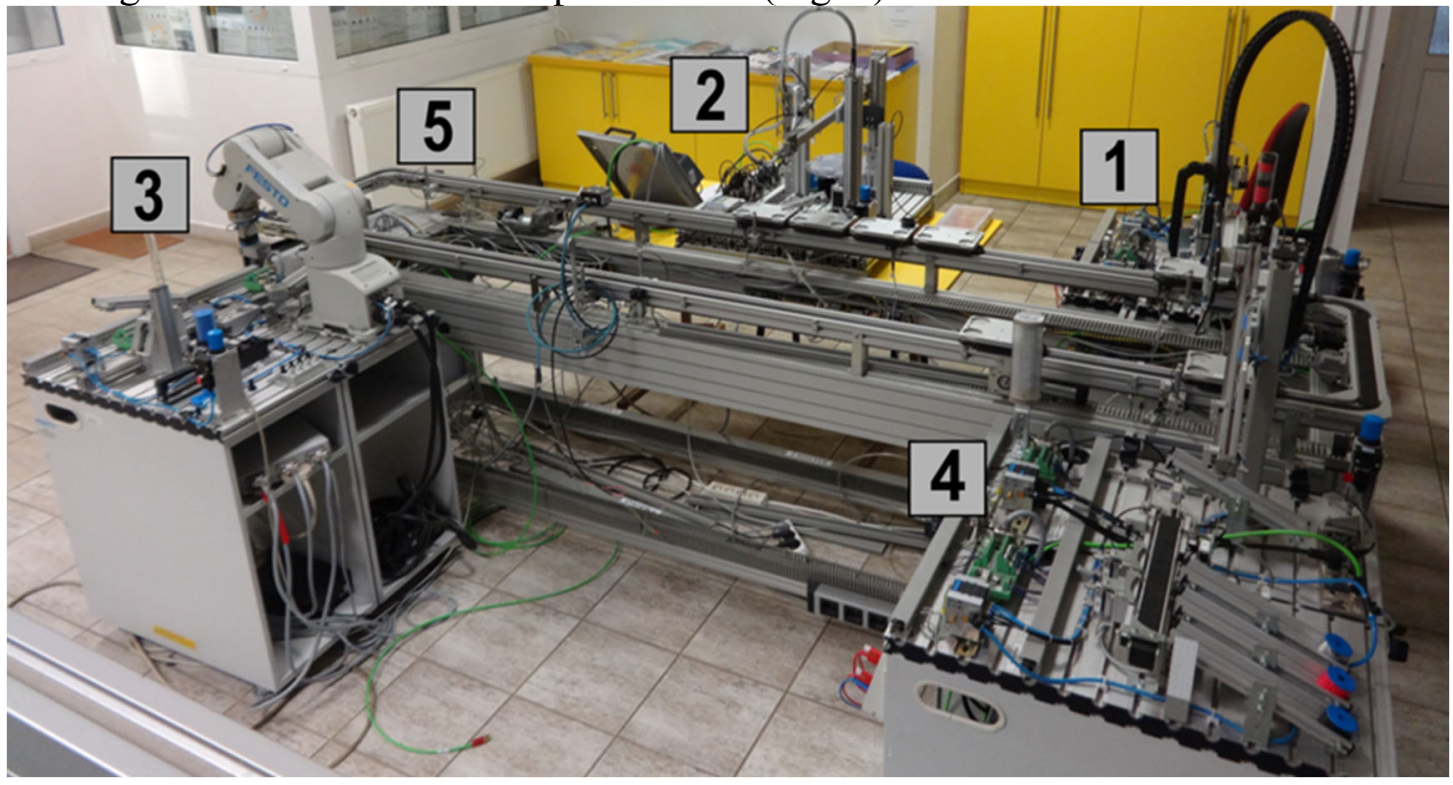

Fig. 1. FESTO automated line with its stations

The automated workplace consists of the following five stations: (1) distribution and testing station, (2) handling and processing station, (3) assembly station with industrial robot, (4) handling and sorting station, (5) conveyor system.

In the beginning, it is necessary to get acquainted with the product on which we will verify the proposed solution. It is crucial because of the processes on this automated line (Fig. 2).

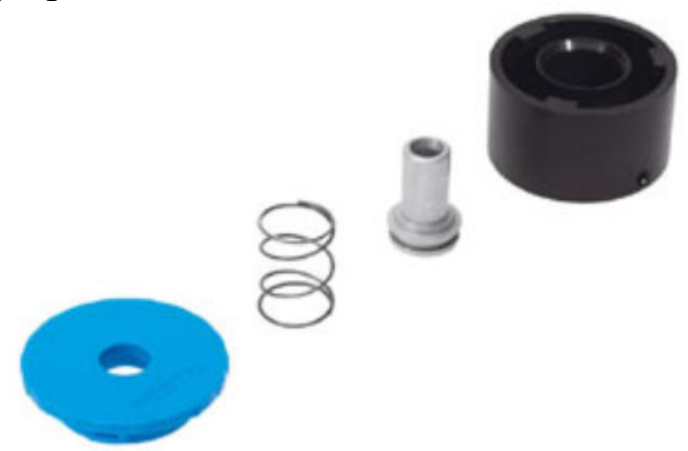

Fig. 2. Decomposed product 
TECHNICAL SCIENCES AND TECHNOLOGIES

There are three types of these products on the line. We can find differences in height, material, color, or weight (Fig. 3).

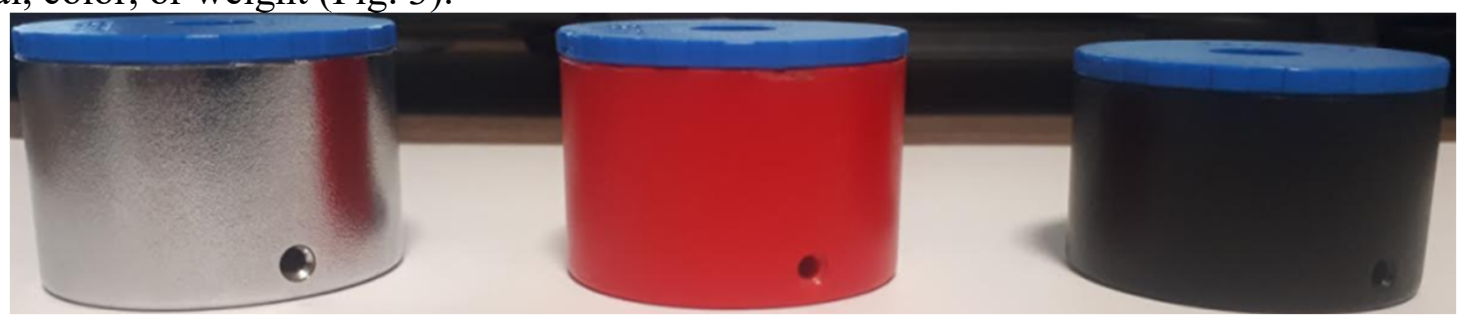

Fig. 3. Assembled product types

The hardware configuration consists of the interconnection of individual components, considering their technical parameters and deployment suitability for the selected automated FESTO system, Fig. 4. Since this workplace has IO-Link technology, we suppose the sensors will be connected using a superior IO-Link master device that will communicate with the PLC. For optimal functionality, it is necessary to use a PLC from Siemens (S7 - 1200).

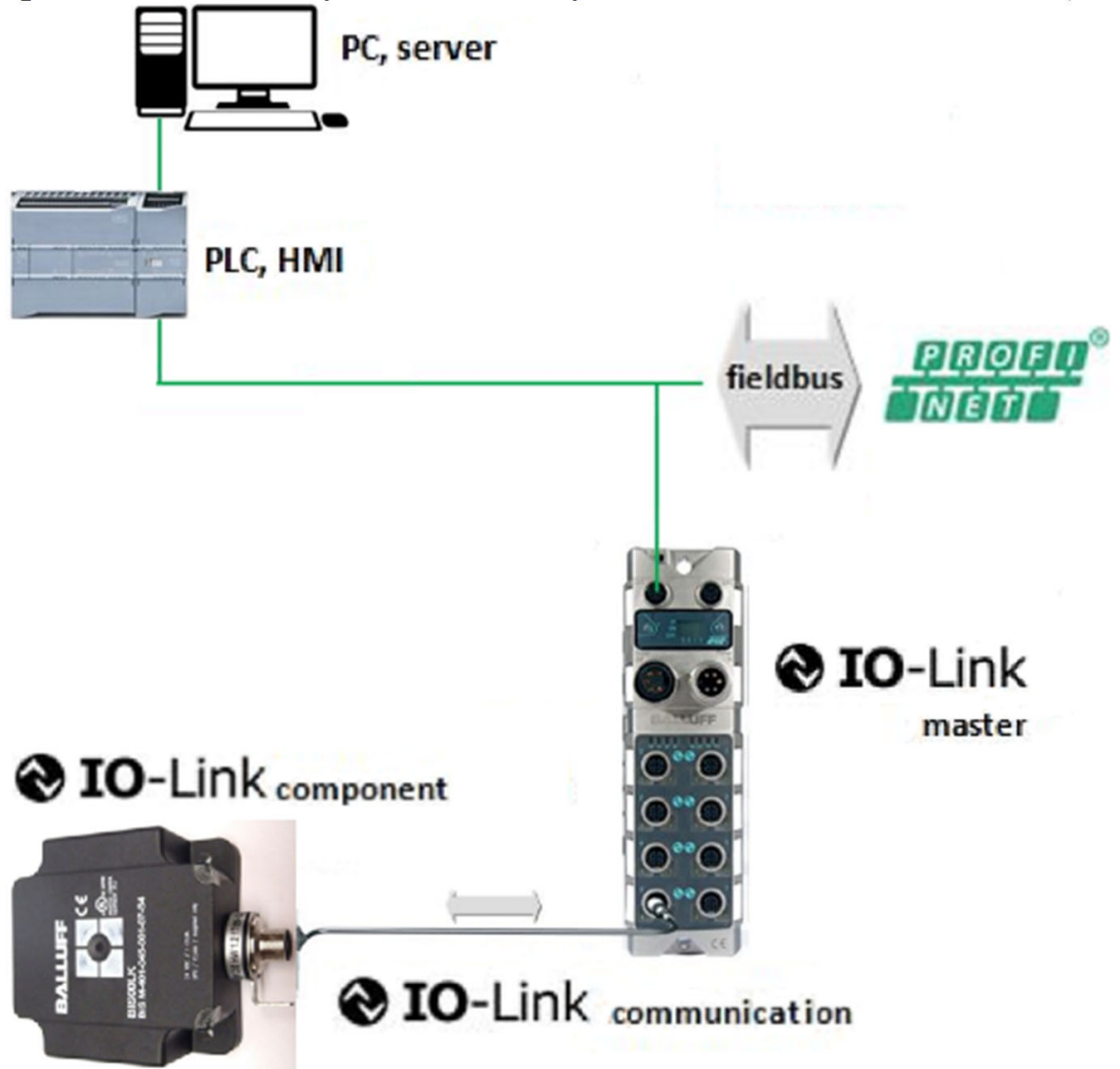

Fig. 4. Hardware configuration setup

The sequence of steps for the hardware configuration of RFID technology for the selected automated FESTO system can be described in the following steps:

- We are creating a new program in the operating software environment from Siemens (TIA Portal). This step includes selection, the addition of the necessary hardware (reading head from BALLUFF, IO-Link master, sensors, and more), and inclusion of a tree of the new program in the project.

- Correct configuration of (previously added) hardware in a software environment is the next step in hardware implementation. This step is necessary to upload the so-called "GSD" component file for the respective IO-Link master. These files are in open access and are usually provided directly by the hardware manufacturer. 
- The next step is implementing the connection and network configuration of the used components in the project tree. The content also includes the setting of the PROFINET network. Part of this step is also assigning the IO controller between the PLC and the IO-Link master.

- If the implementation of the steps mentioned above is successful, the IP address of the IO-Link master will be set. Part of this step is to set the IO-Link device ports and I/ O bytes for each device (RFID head, sensors...)

Software configuration and management of the RFID read head is necessary mainly to collect and process the acquired data, which is possible from the RFID tags. The data collection set up in this way can function as a "stand-alone" solution or being connected to a superior SCADA information system. The creation of the software together with the complete software configuration presupposes the implementation of the following steps:

- Download, open and load a global library of all necessary devices for data collection and evaluation from the automated FESTO workplace. The library also contains the program required and data blocks, which we gradually insert into the organizational "Main" program.

- The next step is to open the organizational "Main" program and assign individual inputs and outputs. In this section, you can set functions such as start, reset, dynamic data acquisition mode, start address, and much more.

- The follow-up and final activity are copying these inputs and outputs to the "Watch" table. Part of the step is to turn on the online mode and monitor the set parameters. Some of them still need to be reset.

We can visualize the processing and collection of acquired data as a general. It is possible through an application running on an HMI panel from Siemens (SIMATIC KTP 700 BASIC). It has a 7-inch widescreen color display and eight function keys. It can be operated by touch or using buttons. It uses the PROFINET interface to connect to a PLC. In addition, it contains a USB interface with which we can click a keyboard, mouse, or other devices. The application screen (Fig. 5) includes a switch displayed in the upper left part, and its task is to switch between readings and write mode. There are also START and RESET buttons on the application screen, located at the top of the screen.

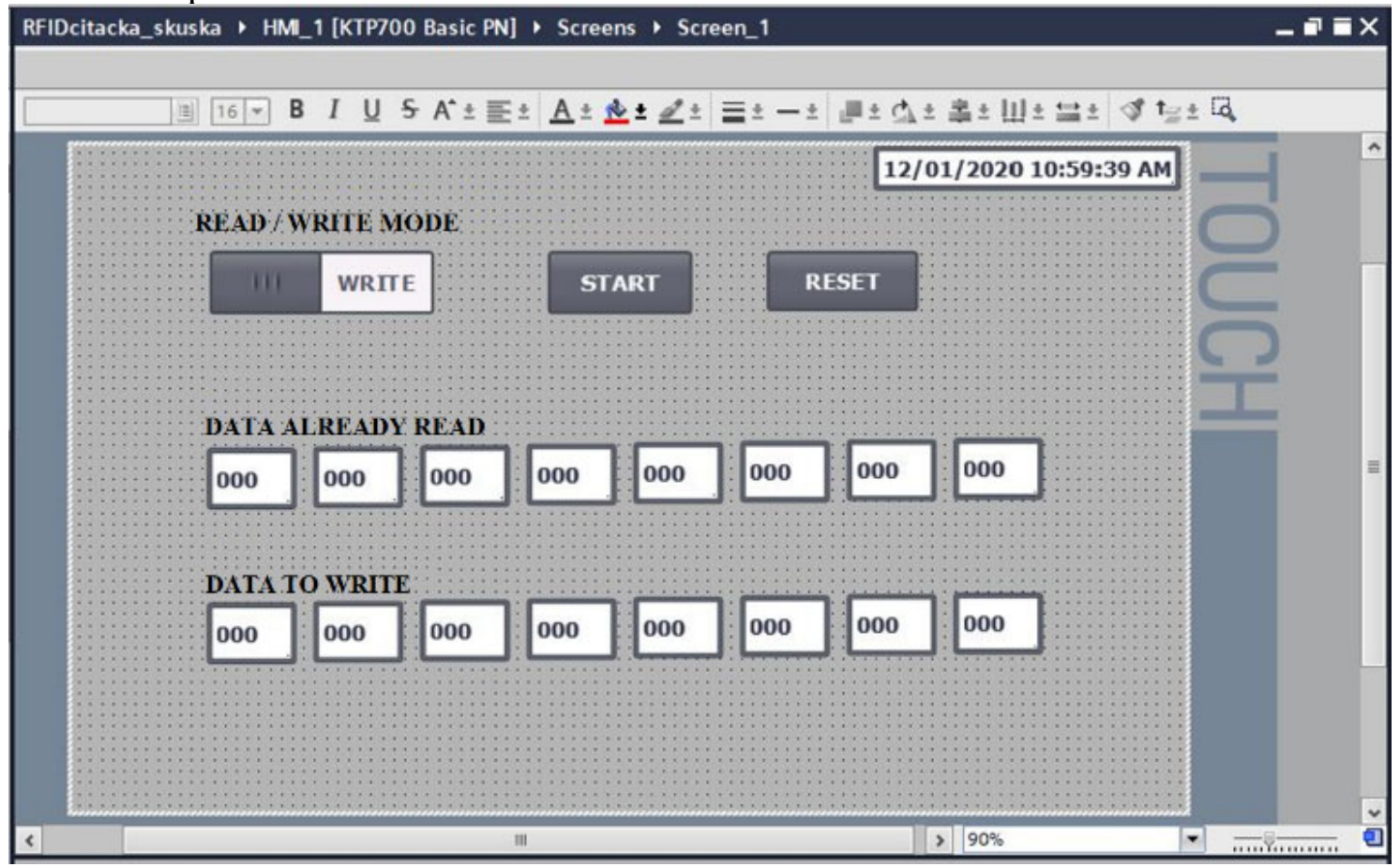

Fig. 5. The application screen at Siemens HMI panel 
TECHNICAL SCIENCES AND TECHNOLOGIES

The START button has the function of starting the reading or writing of data to the RFID tag. We can use the RESET button when changing the reader mode. It is due to ensuring the default state of the processor. In addition to this function, we can also be resetting the writing data. It is displaying in the corresponding boxes at the bottom of the screen. Finally, we can show the read and write data. Since the RFID read head works with a hexadecimal system, we can see the read data in this form. The data entered must also be entered in hexadecimal.

Different architectures are used to collect and process RFID data, and their selection depends on many parameters. For example, RFID data can be corrupting, incomplete, or redundant. The selection and reliability of the RFID read head is also a decisive factor. One of the suitable products for complete processing, visualization, and publication of acquired data can be using the software product "RFID Middleware." It is software that is directly designing for RFID data management and communication within corporate information systems.

This software is using to control the flow of data between RFID readers and enterprise applications. It also filters, aggregates, and gives meaning to the data obtained from RFID tags (Fig. 6).

Middleware provides data routing using various transmission protocols, data translation into multiple formats, and various web services. In addition, RFID middleware usually includes data filtering because sometimes an application may only require a specific type and value of data from tags.

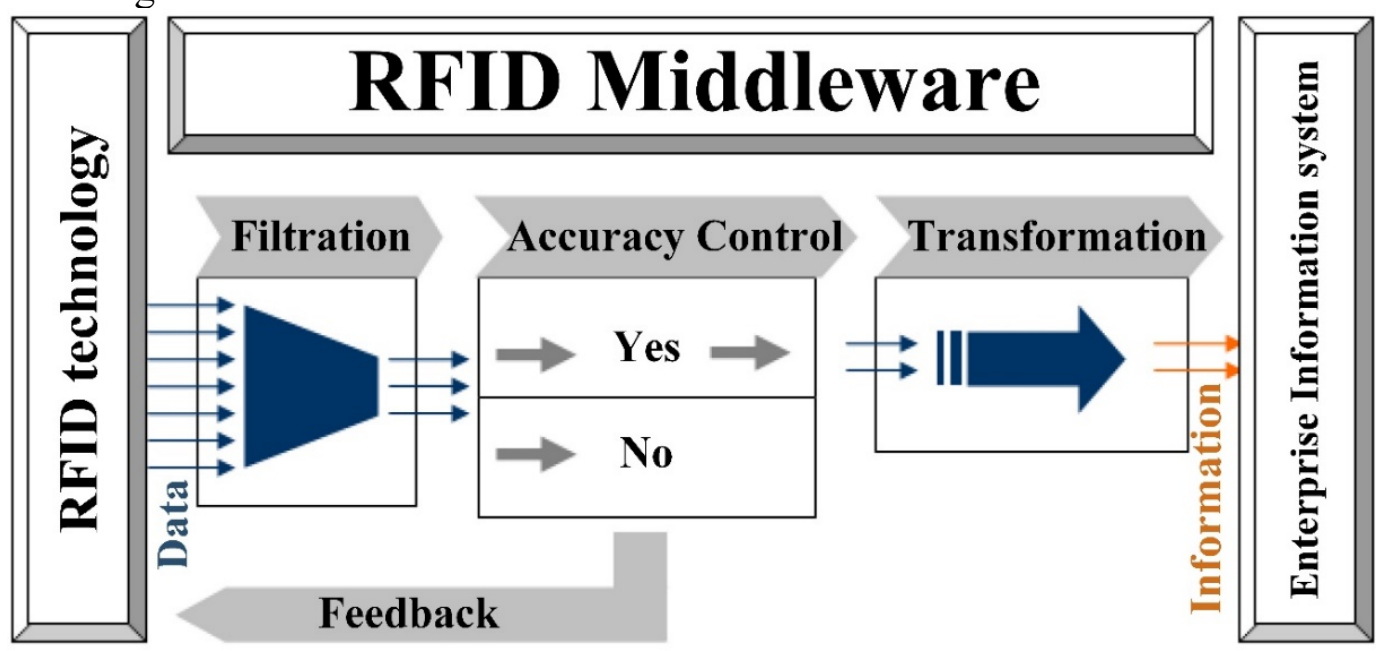

Fig. 6. RFID Middleware [7]

RFID data usually have enormous information, which can lead to the accumulation of their large volumes. In addition, it may lead to slower updates. An essential finding of RFID data is that they usually have a limited lifespan, from when they are first tagged until delivered to the customer. Therefore, they are dividing into an active RFID data set corresponding to frequently updated items and an inactive data set that is no longer updated as often. It makes most data passive over time, speeding up queries for operational data over its lifecycle [7].

Conclusions. Despite the current COVID situation globally, RFID technology has its irreplaceable place and potential for application in various areas of trade and production. It is even likely that this (probably unplanned) slowdown in the world economy may positively impact the increasing demand for this type of technology. Moreover, properly implemented, they are a powerful means of optimizing costs and increasing competitiveness. In our case, it is necessary to note that part of the hardware and software equipment is already at FESTO automated workplace (located at our laboratory). This project is currently in the unfinished phase, and it is only necessary to purchase additional RFID heads and condition monitoring sensors (worth up to 2,000 euros). Ongoing activities will focus on selecting the appropriate process for monitoring and collecting the necessary data. 
Acknowledgment. This work is supported by the Slovak Grant VEGA 1/0330/19 - Research and design of algorithms and systems to fuse heterogeneous data in multisensor architectures and KEGA 044TUKE-4/2021- Remote access to laboratory exercises for industrial automation.

\section{References}

1. Kour, R.; Karim, R.; Parida, A. \& Kumar, U. (2014). Applications of radio frequency identification (RFID) technology with eMaintenance cloud for the railway system. International Journal of System Assurance Engineering Management, 5(1), p. 99-106.

2. Huba, M.; Kozák, S. (2016). From e-learning to Industry 4.0. ICETA 2016. Danvers: IEEE, p. $103-108$.

3. Tůma J.; Wagnerova R.; Farana, R.; Landryova, L.; (2007). Fundamentals of automation. (In original: Základy automatizace). Ostrava: VŠB, Technicka univerzita Ostrava, p. 288.

4. Heynicke, R.; Krush, D.; Cammin, C.; Scholl, G.; Kaercher, B.; Ritter, J.; Gaggero, P.; Rentschler, M. (2018). IO-Link Wireless enhanced factory automation communication for Industry 4.0 applications. Journal of Sensors and Sensor Systems. DOI 10.5162/sensor2017/A8.1.

5. Kaur, M.; Sandhu, M.; Mohan, N.; Sandhu, P. (2011). RFID Technology Principles, Advantages, Limitations \& Its Applications. International Journal of Computer and Electrical Engineering. P.151-157.

6. Panigrahi, R.R.; Jena, D.; Jena, A. (2021). Deployment of RFID Technology in Steel Manufacturing Industry - an Inventory Management Prospective. Advances in Machine Learning and Computational Intelligence edition. Algorithms for Intelligent Systems. Springer, Singapore. https://doi.org/10.1007/978-981-15-5243-4_67.

7. Sarac, A. (2010). Modeling and decision support for introducing RFID technologies in supply chains. Dissertation thesis at Ecole des Mines de Saint-Étienne. P. 198.

Отримано 17.07.2021

УДК 621.941-229.3:621.396.9:004.73

\section{Марек Вагаш, Алена Галайдова}

${ }^{1}$ доктор технічних наук, доцент, факультет машиностроения

Технический университет Кошице (Кошице, Словакия)

E-mail: marek.vagas@tuke.sk. ORCID iD: https://orcid.org/0000-0002-8660-8484

2 професор, факультет машиностроения

Технический университет Кошице (Кошице, Словакия)

E-mail: alena.galajdova@tuke.sk. ORCID iD: https://orcid.org/0000-0003-0128-4191

\section{МОНІТОРИНГ ПРОЦЕСІВ НА ОСНОВI ТЕХНОЛОГІЇ RFID}

Важливо вказати на необхідність впровадження інноваиійних технологій (таких як RFID). Причини в основному в автоматизації складних виробничих ліній і иілих технологічних прочесів.

Метою статті є представити можливості технологї RFID та реалізувати їх на певному автоматизованому робочому місиі від компанії FESTO. Інший намір - окреслити можливості обробки отриманих таким чином даних.

Попередні публікації та дослідження доводять, щзо технологія RFID вже широко поширена у світі і використовується переважно великими компаніями. Проблемою є обробка отриманих даних та їх зберігання, відображення 8 xмapi.

У иій сфері найчастіше використовується комплексне та повне рішення сторонніх виробників, таке як "RFID Midlleware". Тим не мени, ми вважаємо за необхідне вирішити проблему обробки даних за допомогою иієї технології, а також їх зберігання в хмарі.

Метою статті є представити можливості технологіï RFID та реалізувати їх на певному автоматизованому робочому місиі від компанї FESTO. Інший намір - окреслити можливості обробки отриманих таким чином даних.

Метою статті є впровадження технологї RFID в існуюче автоматизоване робоче місие від компанії FESTO. Акцент робиться на програмно -апаратній конфігурації необхідних підкомпонентів.

Цілком ймовірно, щео незважаючи на ситуачію, щฺо триває у світі з COVID, технологія RFID буде впроваджена в більшій мірі. Уповільнення економіки може призвести до запуску прочесів оптимізаиї̈ витрат та підвищення ефективності процесів та послуг.

Ключові слова: Технологія RFID; автоматизоване робоче місце; датчик; BALLUFF.

Рис.: 6. Бібл.: 7 .

Vagas, M., Galajdova, A. (2021). Process monitoring based on RFID technology. Technical sciences and technologies, 3(25), 187-192. 